Copyright (C) 2021 by Cherkas Global University

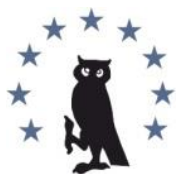

Published in the USA

Slavery: Theory and Practice

Has been issued since 2016.

E-ISSN: 2500-3755

2021. 6(1): 6-13

DOI: 10.13187/slave.2021.1.6

https://stp.cherkasgu.press

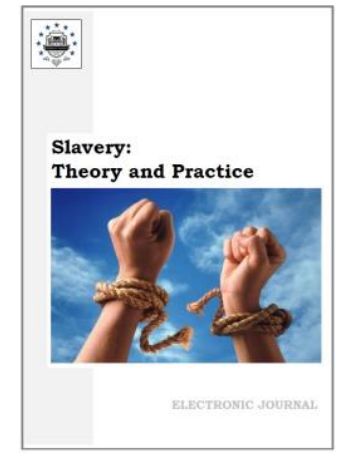

\title{
Articles
}

\section{From the History of Slavery and the Slave Trade in the Belarusian Lands of the X-XIII centuries}

\author{
Evgeniya V. Kravtsova ${ }^{a, *}$ \\ a Kuban State University, Krasnodar, Russian Federation
}

\begin{abstract}
The presented article aims to open a little-studied page in the history of Ancient Rus the phenomenon of slavery and the slave trade in the Belarusian lands in the X-XIII centuries, in an inseparable context from the general Russian trends of socio-economic and political development. On the basis of the materials studied, the study provides a characteristic of the historiographic base corresponding to the stated problem. An article by I.M. Krasnoperov, found in the journal of the Ministry of Education, played a key role in the study «Slavery and the Slave Trade in Ancient Belarus», published in 1907 and is in essence the only scientific study that raised the issue of slavery on the example of a specific region within the framework of the Old Russian state. When analyzing the available information, gaps were identified, including those associated with sources that may become relevant for further comprehensive study and replenishment by historians. In addition, the author made attempts to trace the transformation of such concepts as servant, servant, slave and how they were perceived by contemporaries, as well as to give an answer to the question of why and in what situations sometimes these concepts could be equated to a common denominator. Attention is also paid to the value of owning «human goods» among representatives of the nobility (princes and their entourage). In connection with this provision of the article, an emphasis is placed on the acts of famous princes (especially those of Polotsk) aimed at turning the population into servitude (the activities of Vseslav the Charodey, Gleb Minsky). For a more complete understanding of the level of slavery and the slave trade in the Belarusian lands of the X-XIII centuries, information about the large centers of these phenomena is presented, as well as a description of the main directions of the slave trade (west, east and south) and what contributed to this. As a result, it was concluded that princely strife played a significant role in the development of slaveholding in Ancient Belarus. Taken together, these phenomena provoked a decline and caused enormous damage to both the population and the unity of the state, which is noticeable in the position of the Russian lands in the XIII-XIV centuries.

Keywords: slavery, slave trade, Belarus, Russia, the Principality of Polotsk, Drutsk, yastern Slavs, kholopy, zakupy, chelyad.

\section{1. Введение}

Тема существования рабства у восточных славян в древности является одной из наиболее изучаемых в российской исторической науке и вызывает немало дискуссий,

\footnotetext{
${ }^{*}$ Corresponding author

E-mail addresses: evgeniya-sinchina@yandex.ru (E.V. Kravtsova)
} 
особенно учитывая «неудобность» (Клычников, 2020: 5), стыдливость такой тематики для большинства авторов. Примечательно, что в российской историографии не всё так однозначно даже и в отношении терминов - «раб», «холоп», «челядь», так как с течением эпох значение их изменялось (ЭСБЕ, 1903: 531-538; БСЭ, 1957: 301-302).

Однако, если работ, касающихся теоретических и терминологических проблем, может быть и достаточно, то проявление института рабства на уровне отдельных земель Древней Руси освещено редкими исследованиями. Одним из таких регионов являются белорусские земли ХXIII вв., в особенности - Полоцкое княжество, где также происходили процессы, связанные с рабством и работорговлей. Ввиду того, что проблема является открытой для исследований на сегодняшний день, актуальность ее бесспорна. Для составления наиболее полной картины рабовладельческих отношений и работорговли у славянских племен северо-западных земель Руси, безусловно, необходимо дальнейшее всестороннее изучение этих процессов с привлечением как можно большего количества исторических источников разного характера.

Исходя из изученных нами материалов, целью статьи следует обозначить раскрытие и отображение процессов, связанных с рабовладением и торговлей рабами на примере Древней Белоруссии. Для реализации этой цели поставлены следующие задачи: 1) выявить, какие термины применяли для обозначения зависимых людей и как это соотносилось с понятием «раб»; 2) рассмотреть, какова была экономическая выгода владения «живым товаром» и использования рабского труда для знати (князей, дружинников, бояр); 3) проанализировать деятельность князей (в частности, полоцких), которая касалась обращения населения в зависимых и невольников; 4) охарактеризовать основные невольничьи рынки и направления торговли рабами из белорусских земель.

\section{2. Материалы и методы}

Для написания данной статьи нами были привлечены разнообразные научные труды, касающиеся проблемы рабства и зависимых категорий населения у восточных славян. К работам обобщающего характера можно отнести изыскания С.M. Соловьева, В.О. Ключевского, В.И. Ламанского, А.П. Новосельцева, И.В. Лучицкого, А.А. Зимина, И.Я. Фроянова и др. Сведения, касающиеся социально-экономического развития белорусских земель IX-XIII вв., содержат издания «Гісторыя Беларусі», коллективный сборник «Древнейшие города Беларуси. Полоцк».

Особенно ценной является работа И.М. Красноперова «Рабовладение и работорговля в древней Белоруссии», которая стала базисом для нашего исследования. Опубликована статья была в 1907 г. в декабрьском выпуске «Журнала Министерства народного просвещения», издававшегося в Санкт-Петербурге. Автор Иван Маркович Красноперов - известный русский статистик, этнограф, историк, получивший общественное признание еще при жизни. Увлекаясь краеведением, не обошел он своим вниманием и историю белорусских земель. В работе сделана попытка структурировать имеющиеся сведения по рабству в Древней Белоруссии, а также рассмотреть глубинные причины этого явления, порой даже описывая специфику климата и географическое положение. При этом работа написана без отрыва от общих тенденций развития других восточнославянских земель. Примечательна и обширная историография, на которую опирается автор (И.Е. Забелин, С.М. Соловьев, Е.Ф. Карский, В.Е. Данилович, И.Д. Беляев, И.В. Турчинович, М.О. Коялович, П.П. Мельгунов и др.).

И.М. Красноперов привлек для написания своей статьи еще и источники разного происхождения - фольклорные (белорусские песни), летописи (Новгородская, Ипатьевская), законодательные (Русская Правда), делопроизводства (русско-ливонские акты), а также биографические (житие преподобной Ефросинии Полоцкой) и т.д. Заметим, что проблема источниковой базы по нашей теме заключается в том, что в большинстве своем документы содержат общие или скудные сведения об обращении людей в рабство и уровне работорговли в Древней Руси. Особенно непросто воссоздать картину этих явлений, если речь идет о конкретном регионе, например о северо-западных землях.

Для решения поставленных задач в исследовании применяется общепринятый междисциплинарный аналитический подход, а также социально-исторические методы. Кроме того, статья строится на важных для исторической науки принципах - историзме, объективности и системности. В нашей исследовательской работе были использованы историко-системный, описательный методы и метод детерминизма, благодаря которым 
выявлены основные механизмы обращения в зависимость и рабство в древнерусском обществе, сделаны попытки раскрыть причинно-следственные связи данных явлений, показана роль в этих процессах князей и других представителей знати, а также охарактеризованы термины, которыми обозначали категории зависимых людей.

\section{3. Обсуждение}

Поднимая вопрос о существовании рабовладельческих отношений в Древнерусском государстве, можно обнаружить целую парадигму исследований, касающихся этой проблемы. Фактически в первых трудах по истории России уже встречаются попытки освещения указанной проблематики. Так, например, в труде Татищева В.Н. в главе о древнерусском правительстве содержатся сведения о том, что существовало холопство и рабство, а также дается объяснение, чем они различаются: «Холоп... по договору на время договорное, а раб преодоленный и пленённый есть невольник вечный и наследственный, яко же есть то у некоих обычай, что родители детей своих или пленников других в рабство продавались» (Татищев, 1769: 530). В XIX в. наблюдается тенденция более подробной характеристики уровня рабства и работорговли у восточных славян, а также появляется мнение о домашнем рабстве (например, в работах С.М. Соловьева), а иногда появление рабовладельчества у славян связывали с влиянием пришлых варягов. Несмотря на это, рождаются интересные работы, связанные с явлением рабства и тем, как оно отражалось на восточных славянах. Отметим такие работы, как диссертация «О славянах в Малой Азии, в Африке и Испании» (1859 г.) В.И. Ламанского, где повествуется в том числе и о торговле славянскими пленниками и рабами в арабских землях и Африке, а также «Русские рабы и рабство в Руссильоне в XIV и XV вв.» (1886 г.) И.В. Лучицкого, где впервые рассматривалось положение русских рабов, оказавшихся волею судьбы на территории Франции и др. А в «Энциклопедическом словаре Брокгауза и Ефрона» говорится, что, хотя у славян рабство существовало в основном в патриархальной форме с давних времен, но только «кроме русских» (ЭСБЕ, 1899: 47).

В советской историографии ввиду господства марксистско-ленинской теории позиция историков кардинально менялась и разгорались жаркие дискуссии в рамках изучения общественного строя Древней Руси. Подвести итог под этими научным изысканиям пытался историк И.Я. Фроянов в своей монографии 1996 г. «Рабство и данничество у восточных славян (VI-X вв.)». Он анализирует институты рабства и данничества, выходя за общепринятые рамки в советской науке, и демонстрирует свое видение проблемы, в котором важное влияние на формирование упомянутых институтов оказали духовно-нравственные аспекты.

Несмотря на обилие научных изысканий, касающихся социально-экономических отношений Древней Руси, отдельных работ по ее регионам, где существовали рабовладельчество и работорговля, в современном историческом сообществе практически не представлено. Поэтому особенно важно снова ввести в научный оборот забытую статью И.М. Красноперова «Рабовладение и работорговля в древней Белоруссии». В этой работе можно увидеть не только своеобразие упомянутых явлений в северо-западных землях Руси, но и через их призму попытаться понять процесс рабовладельческих отношений во всем Древнерусском государстве.

\section{4. Результаты}

Белорусские земли в IX-X вв. уже активно включались в политические и экономические отношения с соседями, в том числе с Киевом и Новгородом (Гісторыя Беларусі, 2007: 148). Во многом этому способствовало выгодное природно-климатическое и географическое положение земель. Также довольно рано узнали и скандинавы об этих местах, включенных в ареал «пути из варяг в греки».

Увеличение торгово-экономических взаимоотношений способствовало разложению родоплеменного строя и усилению социальной дифференциации общества. В XI-XII вв. расслоение достигает такого масштаба, что «верхние слои обратили массы в подневольных рабов» (Красноперов, 1907: 316). Князья, бояре и духовенство сосредотачивали в своих руках не только обширные земельные владения, но и имели целые села с челядью, о чем свидетельствует летописи и, например, житие Ефросинии Полоцкой (Красноперов, 1907: 316). Порой число таких челядинов в одном селе могло достигать несколько сотен человек. Появлялись зависимые категории людей и рабов разными способами, но на этом этапе 
преимущественно из-за долговой кабалы либо же путем пленения из других земель. Зачастую положение закупов и рядовичей не особо отличалось от холопского: по «Русской Правде» (статья 62) вполне допускалось бить закупа «за дело» (Русская Правда). По мнению же И.М. Красноперова, «производительные земледельческие классы населения в древней Руси были рабами» (Красноперов, 1907: 317). Этот тезис он выводит из того, что существовали «неролейные закупы», проживавшие при доме своего господина и отрабатывавшие долг личными услугами. Нечто подобное существовало и в германском праве.

Практически не могли владеть никакими политическими правами зависимые категории людей и в землях, где существовала вечевая форма управления, например в белорусском Полоцке, который по форме правления был очень схож с Новгородом (Лысенко, Штыхов, 1966: 10-11). Челядь, рабы, холопы должны были подчиняться и помогать на собраниях вече «в качестве подсобников той или другой партии, или даже влиятельной личности - кулаками, криком» (Красноперов, 1907: 318). Таким образом, экономически зависимых людей зажиточная знать вынуждала выполнять еще и дополнительную работу, не связанную напрямую, скажем, с возвратом «купы» или выполнением «ряда». Такое замечание подчеркивает наличие элементов рабства в древнерусском обществе X-XIII вв. Во время феодальной раздробленности, которая отразилась на развитии всех русских земель, население Древней Белоруссии также было втянуто в усобицы между князьями и подверглось мощной волне насилия и грабежей. Охарактеризовать это можно на примере деятельности известного полоцкого князя Всеслава Брячиславовича (Чародея). Поначалу довольно мирно сосуществуя как с балтийскими, так и другими русскими землями, князь Всеслав Чародей не устраивал крупных и жестоких походов. Однако в 1065 г. он совершает поход на Псков, а в 1066 г. - на Новгород, который разоряет, сжигает и забирает в плен его жителей: «приде Всеслав и възя Новгород, с женами и с детми» (Новгородская летопись..., 1950: 17).

О причинах перехода Полоцкого княжества к столь агрессивной политике существует много предположений, но отметим одно из современных и довольно любопытных, так как оно базируется и на данных археологии: во-первых, в XI в. Новгород фактически монополизировал торговлю пушниной со странами Западной Европы; во-вторых, международная торговля во второй половине XI вв. сосредотачивается по Западной Двине, о чем свидетельствуют обнаруженные монеты (Гісторыя Беларусі, 2007: 157-158).

Что же касается реакции Ярославичей на походы Всеслава, то она была незамедлительной: «братья взяли Минск, мужчин изрубили, жен и детей отдали на щит (в плен) ратникам» (Соловьев). Можно согласиться с И.М. Красноперовым, что такая политика «согласовывалась с общими нравами того времени и была свойственна и другим русским князьям» (Красноперов, 1907: 319). Не избегал подобной практики и князь Владимир Мономах, напавший на Минск в 1071 г. и разграбивший его, не оставив там «ни челядина, ни скотины». Советский историк, академик Б.Д. Греков примечает, что «трудно предположить, чтобы Владимир Мономах с дружиной имели возможность строго различать рабов и не рабов в момент нападения на город Минск. Тут, несомненно, часть населения была истреблена, часть уведена в плен без различия их социального происхождения» (Греков, 2012: 121-122).

В 1101 г. умирает князь Всеслав Чародей и его сильное и обширное княжество распадается на уделы с городами Витебск, Минск, Друцк, Орша и др. Усобицы между наследниками продолжаются и тем самым отрицательно влияют не только на политикоэкономические состояние земель, но и на ухудшение положения низших слоев населения. Каждый князь владел землями, селами, где трудились подневольные - холопы и челядь, которые в основном и становились жертвами феодальных войн. Некоторые исследователи пишут, что полоцкие князья нередко нападали на соседние земли, «уводили оттуда пленных и заселяли ими свою страну», а город Минск «весь заселён был рабами» (Коялович, 1884: 63). Например, историк М.О. Коялович подчеркивает, что «полоцкие князья имели большую нужду в людях и забирали их, где только могли» (Коялович, 1884: 63).

Проводимая полоцкими князьями в X-XIII вв. политика в отношении низших слоев населения и обращение их в зависимых в статье И.М. Красноперова характеризуется как «политика эгоизма» (Красноперов, 1907: 321). Иллюстрацией происходивших военных конфликтов и их последствий на территории Полоцкого княжества в XII в. может быть реконструкция погребального обряда, выполненная в результате археологических 
исследований курганов Друцка белорусскими учеными О.Н. Левко и А.В. Войтехович. Обнаруженное массовое захоронение в кургане состояло из представителей разных слоев населения: вероятно, это было княжеское семейство со своим окружением и слугами. Примечательно, что почти все они погибли насильственной смертью (Левко, Войтехович, 2010: 377).

Упоминаемый выше город Друцк имел непростую и насыщенную историю, связанную с работорговлей. На данный момент на месте легендарного Друцка в Белоруссии находится одно из крупнейших городищ, раскопки которого активно ведутся. Отсюда появляются благодаря археологическим находкам представления о Друцке как о богатом и укрепленном городе. Также есть свидетельства в фольклорных и письменных источниках, что у Друцка была и другая, «темная сторона» - город являлся центром работорговли и был известен именно из-за этой деятельности за пределами Древней Белоруссии.

В начале XII в. Друцк входил во владения минского князя Глеба Всеславича, который смог пошатнуть позиции вече и «безнаказанно проявлял свои рабовладельческие инстинкты» - совершал набеги на чужие владения, крестьян продавал в рабство и даже поощрял это занятие среди своих бояр (Красноперов, 1907: 321). Деятельность Глеба, например известное сожжение Слуцка, привела к тому, что против него выступили Владимир Мономах с сыновьями, а также черниговские князья. Ими были разорены города Орша, Копысь (перевалочный пункт работорговцев, откуда они отправляли «живой товар» на восток), а также осажден и захвачен Друцк, невольничий рынок которого сжег сын Владимира Мономаха - Ярополк. Оставшееся население Ярополк «переселил на лодках по Днепру в свое Переяславское княжество, построив для них новый город при впадении реки Сулы в Днепр - Желди» (Красноперов, 1907: 321-322). Восстановление города произойдет только почти через полвека. Князь Глеб умер, находясь в плену в Киеве. Жена его, Анастасия Ярополковна, оставила распоряжение, в одном из пунктов которого завещала КиевоПечерской лавре 5 сел с челядью (ПСРЛ, 1871: 338).

Что касается направлений работорговли, то для купцов из приднестровских земель это были прежде всего половецкие территории. Начиная с X в., экспортировали пушнину, продукты бортничества, а также челядь, получая взамен лошадей, рогатый скот. Примечательно, что набеги за рабами совершали обе стороны: как половцы, так и русские князья с дружиной. И.М. Красноперов приводит в качестве доказательства выдержки из «Слова о полку Игореве» о походе князя Олега на половцев, а также о том, как ценились половецкие мальчики в качестве рабов у венгерских правителей (Красноперов, 1907: 323).

Другим потенциальным направлением сбыта рабов была Византия, а именно Константинополь, где находилась крупнейшая площадка для торговли рабами, в том числе и славянскими. Из белорусских и соседних с ними земель «живой товар» отправляли по Днепру на лодках, в которых умещалось 50 и более закованных рабов (Красноперов, 1907: 324). Далее русских невольников везли в арабские владения, где их также очень охотно приобретали местные работорговцы, хотя иногда они сами посещали Древнюю Русь для указанного промысла.

Третьим направлением работорговли из белорусских земель можем считать германские города (например, Ахен, затем Рига). Любопытный пример из русско-ливонских актов за 1286 г. приводит И.М. Красноперов в своей статье: от немецкого купца поступила жалоба на имя витебского князя о том, что его избили и ограбили во время того, когда он «отправился, вооруженный мечом, в полоцкую землю, чтобы у русских "девки купити"» (Красноперов, 1907: 328).

Широко известно, что славянские рабы очень ценились ввиду своей работоспособности, а женщины из-за красоты охотно приобретались в качестве наложниц. Поэтому торговля рабами на территории Древней Руси X-XIII вв. стала явлением массовым и привычным, порой почти не имеющим общественного порицания. Реакция низших слоев населения на обращение в рабство и продажу своими же соотечественниками выразилась в бегстве. Так, многие крестьяне и челядь бежали из родных земель под предлогом паломничества к христианским святыням, из которого уже не возвращались (Красноперов, 1907: 331). Бывали случаи, когда бежали от несправедливости, невежества и насилия над личностью даже знатные люди. Примером выбора своей судьбы и символом противостояния рабовладельческим нравам того времени И.М. Красноперов считает преподобную Ефросинию Полоцкую, внучку Всеслава 
Чародея, которая без дозволения родителей приняла монашеский постриг. Принятие сана помогло ей активно участвовать в общественной жизни, заниматься просветительской деятельностью, а также влиять на политическую жизнь: она зачастую выступала с миротворческих позиций в усобицах между князьями. В особенности явление бегства отчетливо прослеживается с XII в. на волне княжеских усобиц, когда массово крестьяне и категории зависимого населения ищут спасение на севере Руси, в Ростово-Суздальской земле, на Волге и т.д. Пустеют и белорусские земли, когда-то густозаселенные в районе Днепра и его притоков, и, соответственно, ухудшается социально-экономическое положение дел в княжествах, здесь расположенных, в политической сфере они перестают превалировать над другими древнерусскими княжествами и не способны противостоять совместно монгольской угрозе. Так, Половецкое княжество в XIII в. во многом по этим причинам сдается власти литовских феодалов.

\section{5. Заключение}

Рабство и работорговля в белорусских землях были известны довольно рано. Упоминаются эти явления в источниках здесь уже с X в. По мере углубления социальноимущественного расслоения древнерусского общества и развития феодальных отношений процесс обращения в зависимость и рабство низших слоев населения заметно ускоряется. Смеем предположить, что, несмотря на скудность данных в источниках о рабстве и работорговле у восточных славян, это явление не было чем-то диковинным или неестественным, даже наоборот, рабство и продажа «живого товара» были делом привычным и повсеместным, о чем свидетельствуют, к примеру, древнерусские летописи. Порой современники приравнивали к рабам и обращенных в зависимость (челядь, холопов). Изученные материалы говорят о том, что иногда экономическое подчинение перерастало в притеснение человеческой воли. Даже не спасал от этого и такой народный орган управления, как вече.

Княжеские междоусобицы легли тяжелым бременем на плечи народа. Борьба правителей за власть и территории зачастую сопровождалась грабежами, сожжением городов, убийствами, насилиями, и, конечно же, пленные становились для многих желанным трофеем, который легко можно было сбыть по выгодной цене. Тем более что не только через белорусские земли, но и другие древнерусские княжества проходили крупные международные торговые пути.

Благодаря популярности работорговли в XI-XII вв. на территории северо-западных земель появляются ее специализированные центры: так, города Копысь (место, где останавливалось много купцов и работорговцев перед тем, как отправиться с «живым товаром» за пределы Руси) и главный невольничий рынок - Друцк, от которого на территории Белоруссии в наши дни остался крупнейший археологический памятник средневекового городища. Отсюда работорговля велась в нескольких направлениях в Западную Европу, половецкие степи, Византию и еще далее: русские рабы были желанным товаром в арабских землях.

Частые усобицы и существовавшие рабовладельческие тенденции в X-XIII вв. не могли привести древнерусское общество к стабильности. Развитие рабства и работорговли стало одним из характерных черт феодальной раздробленности и внутреннего кризиса. Массовое бегство населения способствовало разорению княжеств, их запустению, что в дальнейшем, безусловно, отразилось на политической истории белорусских и других древнерусских земель.

\section{Литература}

БСЭ, 1957 - Большая советская энциклопедия. В 50 т. М., 1957. Т. 46. С. 301-302.

Греков, 2012 - Греков Б.Д. Грозная Киевская Русь. М.: Алгоритм, 2012. 256 с.

Коялович, 1884 - Коялович М.О. Чтения по истории Западной России. СПб.: Тип. А.С. Суворина, 1884.349 с.

Красноперов, 1907 - Красноперов И.М. Рабовладение и работорговля в древней Белоруссии // Журнал Министерства народного просвещения. 1907. Ч. XII. С. 312-331. 
Левко, Войтехович, 2010 - Левко О.Н., Войтехович А.В. Курган с массовыми погребениями XII века в Друцке // Археологія і давня історія України. К., 2010. Вип. 1: Проблеми давньоруської та середньовічної археології. С. 371-378.

Лысенко, 1966 - Лысенко П.Ф., Штыхов Г.В. Древнейшие города Белоруссии. Минск: Наука и техника, 1966. 84 с.

Новгородская летопись..., 1950 - Новгородская летопись старшего и младшего изводов // Под ред. и с предисл. А.Н. Насонова. М.; Л.: Изд-во Акад. наук СССР, 1950. 642 с.

ПСРЛ, 1871 - Полное собрание русских летописей. Летопись по Ипатскому списку. В 24 т. СПб., 1871. Т. 2. 706 с.

Русская Правда - Русская Правда (пространная редакция) // Электронные публикации Института русской литературы (Пушкинского Дома) PAH. [Электронный ресурс]. URL: http://lib.pushkinskijdom.ru/Default.aspx?tabid=4947 (дата обращения: 01.10.21).

Соловьев - Соловъев С.M. История России с древнейших времен. Т. 2. Гл. 2. // Православный портал «Азбука веры» [Электронный pecypc]. URL: https://azbyka.ru/ otechnik/Sergej_Solovev/istorija-rossii-s-drevnejshih-vremen/2_2 (дата обращения: 01.10.21).

Татищев, 1769 - Татищев В.Н. История Российская с древнейших времен. В 5 т. М., 1769. Кн. 1. Ч. 2. $379 \mathrm{c.}$

Фроянов, 1996 - Фроянов И.Я. Рабство и данничество у восточных славян (VI-X вв.). СПб.: Изд-во С.-Петерб. ун-та, 1996. 512 с.

ЭСБЕ, 1899 - Энциклопедический словарь Брокгауза и Ефрона. В 41-м т. СПб., 1899. T. 26. C. $35-52$.

ЭСБЕ, 1903 - Энциклопедический словарь Брокгауза и Ефрона. В 41 т. Т. 37А. СПб., 1903. C. $531-538$.

Гісторыя Беларусі, 2007 - Гісторыя Беларусі. У 6 т. Старажытная Беларусь: Ад першапачатковаго засялення да сярэдзіны XIII ст. / Рэдкал. М. Касцюк (гал. рэд.) і іншп. Мінск: Экаперспектыва, 2007. Т. 1. 351 с.

Klychnikov, 2020 - Klychnikov Yu.Yu. North Caucasian "Hotbed" of the Slave Trade (Trade of Captives): to the Problem Statement // Slavery: Theory and Practice. 2020. 5(1): 4-18.

\section{References}

BSE, 1957 - Bol'shaya sovetskaya enciklopediya [Great Soviet Encyclopedia]. V 50-ti t. M., 1957. Vol. 46. Pp. 301-302. [in Russian]

ESBE, 1899 - Enciklopedicheskij slovar' Brokgauza i Efrona [Encyclopedic Dictionary of Brockhaus and Efron]. V 41-m t. SPb., 1899. Vol. 26. P. 35-52. [in Russian]

ESBE, 1903 - Enciklopedicheskij slovar' Brokgauza i Efrona [Encyclopedic Dictionary of Brockhaus and Efron]. V 41-m t. SPb., 1903. Vol. 37A. P. 531-538. [in Russian]

Froyanov, 1996 - Froyanov, I.Ya. (1996). Rabstvo i dannichestvo u vostochnyh slavyan (VI-X vv.) [Slavery and tributary among the Eastern Slavs (VI-X centuries)]. SPb.: Izd-vo S.-Peterb. un-ta, 512 p. [in Russian]

Grekov, 2012 - Grekov, B.D. (2012). Groznaya Kievskaya Rus' [Formidable Kievan Rus]. M.: Algoritm, 256 p. [in Russian]

History of Belarus, 2007 - History of Belarus. In 6 vols. Ancient Belarus: From the initial settlement to the middle of the XIII century. Ed. M. Kostyuk (ed.) and others. Minsk: Ekoperspektyva, 2007. Vol. 1. 351 p. [in Belarusian]

Klychnikov, 2020 - Klychnikov, Yu.Yu. (2020). North Caucasian "Hotbed" of the Slave Trade (Trade of Captives): to the Problem Statement. Slavery: Theory and Practice. 5(1): 4-18.

Koyalovich, 1884 - Koyalovich, M.O. (1884). Chteniya po istorii Zapadnoj Rossii [Readings on the history of Western Russia]. SPb.: Tip. A. S. Suvorina, 349 p. [in Russian]

Krasnoperov, 1907 - Krasnoperov, I.M. (1907). Rabovladenie i rabotorgovlya v drevnej Belorussii [Slavery and the slave trade in ancient Belarus]. Zhurnal Ministerstva narodnogo prosveshcheniya. Ch. XII. Pp. 312-331. [in Russian]

Levko, Vojtekhovich, 2010 - Levko, O.N., Vojtekhovich, A.V. (2010). Kurgan s massovymi pogrebeniyami XII veka v Drucke [Mound with mass burials of the 12th century in Drutsk]. Arheologiya i davnya istoriya Ukraïni. K. Vip.1: Problemi davn'orus'koï ta seredn'ovichnoï arheologiï. Pp. 371-378. [in Russian] 
Lysenko, Shtyhov, 1966 - Lysenko, P.F., Shtyhov, G.V. (1966). Drevnejshie goroda Belorussii [The oldest cities of Belarus]. Minsk: «Nauka i tekhnika», 84 p. [in Russian]

Novgorodskaya letopis'..., 1950 - Novgorodskaya letopis' starshego i mladshego izvodov [The Novgorod Chronicle of the Elder and the Younger Elimination]. Pod red. i s predisl. A.N. Nasonova. M.; L., Izd-vo Akad. Nauk SSSR, 1950. 642 p. [in Russian]

PSRL, 1871 - Polnoe sobranie russkih letopisej. Letopis' po Ipatskomu spisku [Complete collection of Russian chronicles. Chronicle according to the Ipat list]. V 24-h t. SPb., 1871. Vol. 2. 706 p. [in Russian]

Russkaya Pravda - Russkaya Pravda (prostrannaya redakciya) [Russian Truth (lengthy edition)]. Elektronnye publikacii Instituta russkoj literatury (Pushkinskogo Doma) RAN. [Electronic resource]. URL: http://lib.pushkinskijdom.ru/Default.aspx?tabid=4947 (date of access: 01.10.21). [in Russian]

Solov'ev - Solov'ev, S.M. Istoriya Rossii s drevnejshih vremen. T. 2. Gl. 2. [History of Russia since ancient times. Vol. 2. Ch. 2]. Pravoslavnyj portal «Azbuka very». [Electronic resource]. URL: https://azbyka.ru/otechnik/Sergej_Solovev/istorija-rossii-s-drevnejshih-vremen/2_2 (date of access: 01.10.21). [in Russian]

Tatishchev, 1769 - Tatishchev, V.N. (1769). Istoriya Rossijskaya s drevnejshih vremen [Russian history since ancient times]. V 5-ti t. M. Vol. 1. Ch. 2. 379 p. [in Russian]

\title{
Из истории рабства и работорговли в белорусских землях X-XIII вв.
}

\author{
Евгения Владимировна Кравцова а , *

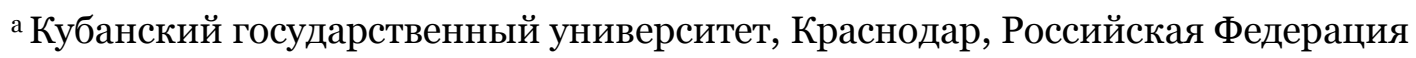

Аннотация. Представленная статья ставит своей целью открыть малоизученную страницу истории Древней Руси - явления рабства и работорговли в белорусских землях в XXIII вв. - в неотрывном контексте от общерусских тенденций социально-экономического и политического развития. На основе изученных материалов в исследовании дается характеристика историографической базы, соответствующая заявленной проблеме. Ключевую роль в исследовании сыграла обнаруженная в журнале Министерства просвещения статья И.М. Красноперова «Рабство и работорговля в древней Белоруссии», опубликованная в 1907 г. и являющаяся по своей сути единственным научным изысканием, поднявшим вопрос о рабовладении на примере конкретного региона в рамках Древнерусского государства. При анализе имеющихся сведений выявлены лакуны, связанные в том числе и с источниками, которые могут стать актуальными для дальнейшего всестороннего изучения и восполнения историками. Помимо этого, автором сделаны попытки проследить трансформацию понятий «холоп», «челядь», «раб» и как они воспринимались современниками, а также дать ответ на вопрос, почему и в каких ситуациях иногда эти понятия могли приравниваться к общему знаменателю. Также обращено внимание на ценность владения «живым товаром» среди представителей знати (князей и их приближенных). В связи с этим положением статьи сделан акцент на деяниях известных князей (особенно полоцких), направленных на обращение населения в подневольное (деятельность Всеслава Чародея, Глеба Минского). Для более полного представления об уровне рабства и работорговли в белорусских землях X-XIII вв. представлены сведения о крупных центрах этих явлений, а также дана характеристика основным направлениям работорговли (запад, восток и юг) и что этому способствовало. Сделан вывод о том, что существенную роль в развитии рабовладения Древней Белоруссии сыграли княжеские усобицы. В совокупности же эти явления спровоцировали упадок и нанесли огромный ущерб как населению, так и единству государства, что заметно на положении русских земель в XIII-XIV вв.

Ключевые слова: рабство, работорговля, Белоруссия, Русь, Полоцкое княжество, Друцк, восточные славяне, холопы, закупы, челядь.

\footnotetext{
* Корреспондирующий автор

Адреса электронной почты: evgeniya-sinchina@yandex.ru (Е.В. Кравцова)
} 